\title{
Jurist-Diction
}

Volume 4 No. 6, November 202

\section{Kebijakan Bea Masuk Impor Barang E-commerce Dalam Kaitannya Dengan Hukum Persaingan Usaha}

\author{
Adelia Rizky Windyaka
}

Adelia.rizky.windyaka-2017@unair.ac.id

Universitas Airlangga

How to cite:

Adelia Rizky Windyaka,

'Kebijakan Bea Masuk Impor

Barang E-commerce Dalam

Kaitannya Dengan Hukum

Persaingan Usaha' (2021) Vol.

4 No. 6 Jurist-Diction.

\section{Histori artikel:}

Submit 6 April 2021;

Diterima 15 Oktober 2021;

Diterbitkan 5 November 2021.

DOI:

10.20473/jd.v4i6.31837

p-ISSN: 2721-8392

e-ISSN: $2655-8297$

\begin{abstract}
The government made Law Number 5 of 1999 concerning the prohibition of monopolistic practices and unfair business competition to regulate business actors in carrying out activities related to buying and selling in the market. The birth of this regulation provides a limit for business actors to create healthy business competition. The presence of a platform for online shopping also makes trading activities easier today. The development of this shopping style also affects the number of imported goods that enter Indonesia. There is a policy regarding the setting of the value for import duties on imported goods which has increased from the previous one. The change in the value of this import duty is a step by the government to protect domestic business actors. Keywords: Law; Bussiness competition; Policy; Import.
\end{abstract}

\begin{abstract}
Abstrak
Pemerintah membuat Undang - Undang Nomor 5 tahun 1999 tentang larangan praktek monopoli dan persaingan usaha tidak sehat untuk mengatur pelaku usaha dalam melakukan kegiatan yang berkaitan dengan jual beli didalam pasar. Lahirnya peraturan ini memberikan batasan bagi pelaku usaha agar menciptakan persaingan usaha yang sehat. Hadirnya platform untuk berbelanja online juga mempermudah kegiatan perdagangan saat ini. Berkembangnya gaya berbelanja ini juga berpengaruh terhadap banyaknya barang impor yang masuk ke Indonesia. Terdapat kebijakan mengenai pengaturan besaran nilai bagi bea masuk barang impor yang mengalami kenaikan dari sebelumnya. Berubahnya nilai bea masuk ini sebagai langkah pemerintah melindungi pelaku usaha domestik.

Kata Kunci: Hukum; Persaingan Usaha; Kebijakan; Impor.
\end{abstract}

Copyright (C) 2021 Adelia Rizky Windyaka

\section{Pendahuluan}

Globalisasi adalah integrasi dalam ruang lingkup internasional dimana ada pertukaran pemikiran, budaya, sampai kebiasaan yang mempengaruhi segala aspek kehidupan mulai dari ekonomi, budaya, pendidikan, politik, hingga perdagangan. ${ }^{1}$

${ }^{1}$ Ferdiansyah, 'Globalisasi Ekonomi, Integrasi Ekonomi Global, Dinamika Pasar modal \& Kebutuhan Standar Akuntasi Internasional' (2016) 8 Jurnal Akuntasi STIE STAN.[120]. 
Perdagangan merupakan aspek penting di dalam sebuah negara, karena merupakan salah satu penentu didalam stabilitas ekonomi. Negara yang memiliki siklus perdagangan yang lancar dengan jumlah ekspor dan impor yang seimbang akan mendapat banyak keuntungan. Pelaku usaha domestik sebisa mungkin diberikan dukungan berupa edukasi dan kemudahan dalam proses menjalankan usahanya oleh pemerintah demi kelancaran proses perdagangan. Pemerintah juga harus mengawasi kebijakan-kebijakan terkait yang menyangkut masalah impor demi menjaga siklus peredaran barang impor yang ada di Indonesia, karena bila terlalu banyak impor yang masuk ke negara bukan merupakan suatu keadaan yang menguntungkan bagi negara tersebut apalagi di zaman sekarang yang semakin maju dalam teknologi. Kemajuan teknologi ini lalu berdampak terhadap perubahan gaya berbelanja yang dilakukan oleh masyarakat. Salah satu media dalam melakukan perdagangan melalui sistem elektronik adalah menggunakan e-commerce. E-commerce merupakan wadah dalam sebuah proses pembelian, penjualan atau pertukaran barang/jasa dan informasi melalui jaringan komputer termasuk internet. Bagi konsumen, dengan adanya e-commerce memberikan kemudahan dalam berbelanja karena efektif, efisien, dan fleksibel. ${ }^{2}$ Produsen dalam hal ini juga mendapatkan keuntungan dari adanya e-commerce yaitu berupa kemudahan dalam memperluas penjualan produk mereka, biaya yang terkendali, dan cash flow yang terjamin. ${ }^{3}$ Produsen bahkan bisa memasarkan produknya hingga keluar negeri tanpa perlu merasa khawatir karena kemajuan perdagangan online ini juga ditunjang dengan adanya kemajuan dalam hal pengiriman barang.

Bertambah majunya dunia perdagangan yang dipermudah dengan hadirnya e-commerce membuka pangsa pasar yang lebih luas bagi para produsen. Datangnya produk dari luar negeri dengan harga yang lebih murah menciptakan hambatan bagi produsen lokal untuk memasarkan produknya di negeri sendiri. Sadar akan celah yang ada ini pemerintah mengeluarkan kebijakan baru yang terdapat dalam Peraturan Menteri Keuangan Nomor 199/ PMK.010 / 2019 tentang Kepabeanan, Cukai, dan

\footnotetext{
${ }^{2}$ Candra Ahmadi dan Dadang Hermawan, E-Business \& E-Commerce (Andi Offset 2013).[12].

${ }^{3}$ ibid.
} 
Pajak atas Impor Barang Kiriman. Pemerintah dalam peraturan ini menetukan kebijakan baru berupa penurunan nilai pembebasan bea masuk atas barang impor yang mulanya USD 75 menjadi USD 3. Pengaturan yang terdahulu yaitu pada Peraturan Menteri Keuangan Nomor 112/PMK.04/2018 tentang Perubahan atas Peraturan Menteri Keuangan Nomor 182/PMK.04/2016 tentang Ketentuan Impor Barang Kiriman disebutkan dalam pasal 13 bahwa barang kiriman yang di impor dapat diberikan pembebasan bea masuk dengan nilai pabean paling banyak sebesar USD 75, sedangkan dalam peraturan terbaru, Peraturan Menteri Keuangan Nomor 199/ PMK.010 / 2019 tentang Kepabeanan, Cukai, dan Pajak atas Impor Barang Kiriman pada pasal 13 menyebutkan bahwa terkait barang kiriman yang di impor dapat diberikan pembebasan bea masuk dengan nilai pabean paling banyak USD 3 . Ini memiliki arti bahwa barang impor yang memiliki harga lebih dari USD 3 akan dikenakan bea masuk impor. Hal ini dinamakan penurunan terhadap De Minimis. De Minimis merupakan nilai pembebasan terhadap bea masuk suatu barang dari luar negeri yang akan masuk ke Indonesia. Hal ini merupakan kabar baik bagi produsen lokal karena dengan kebijakan baru ini maka produk impor yang harganya relatif murah pun akan tetap dikenakan pajak bila masuk ke Indonesia, bila harga produk dari luar dan dalam negeri memiliki harga yang setara dalam artian tidak memiliki perbedaan yang signifikan dengan kualitas yang sama maka akan menciptakan persaingan usaha yang sehat didalamnya.

\section{Perlindungan Bagi Pelaku Usaha Domestik}

Bentuk perlindungan yang diberikan oleh pemerintah berupa peraturan yang mengatur tentang hak dan kewajiban pelaku usaha yang terdapat dalam Undang-Undang nomor 5 tahun 1999 tentang anti monopoli serta pemerintah juga memberikan perlindungan berupa antisipasi terhadap banyaknya barang impor yang dapat mempengaruhi penjualan pelaku usaha domestik dengan menetapkan Peraturan Menteri Nomor 119 /PMK.010/ 2019 yang mengatur mengenai kepabeanan,cukai, dan pajak bagi barang impor. Indonesia merupakan pasar yang sangat menguntungkan untuk diadakannya kegiatan impor, karena jumlah 
penduduknya yang banyak. Banyaknya jumlah penduduk ini mendorong pemerintah untuk melakukan kegiatan impor karena kapasitas dalam negeri yang tidak mampu memenuhi permintaan konsumen. ${ }^{4}$ Majunya sektor perdagangan didalam negeri ini berpengaruh terhadap pendapatan yang diterima oleh masyarakatnya. Meningkatnya pendapatan yang diterima mempengaruhi daya beli masyarakat terhadap suatu barang ataupun jasa, dengan banyaknya permintaan yang datang, pelaku usaha domestik tidak dapat memenuhi semua permintaan yang ada maka diadakanlah kegiatan impor untuk memenuhi permintaan dari konsumen. Pelaku usaha dalam melakukan kegiatan produksinya memerlukan berbagai biaya untuk menghasilkan produk. Pengeluaran yang digunakan untuk membeli bahan pokok, untuk menggaji para pegawai tiap bulan, dan pengeluaran untuk bahan pendukung lainnya masuk ke dalam biaya untuk proses produksi, maka bila pengeluaran untuk biaya-biaya tersebut meningkat akan membuat pelaku usaha menaikkan harga barang untuk menutupi kerugian yang ada, karena sekali lagi tujuan dari pelaku usaha adalah untuk mendapatkan keuntungan sebanyak mungkin dengan kerugian yang paling sedikit.

Sektor perdagangan yang rawan terhadap banyaknya barang impor yang masuk ke Indonesia adalah para pelaku usaha domestik dengan skala kecil. Pelaku usaha domestik dianggap dalam menghasilkan sebuah produk masih kurang bervariasi, kualitasnya tergolong rendah, dan harga yang relatif lebih mahal daripada produk impor yang beredar dipasaran. ${ }^{5}$ Konsumen dalam melakukan pembelian tentu saja akan memilih barang yang memiliki harga terendah untuk menguntungkannya dirinya. Mengatasi hal ini pemerintah harus ikut andil dalam melindungi pelaku usaha yang ada didalam negeri, dengan cara menetapkan tarif bea masuk terhadap barang-barang dengan harga yang melebihi USD 3. Nilai yang rendah ini diharap dapat menghambat banyaknya produk yang masuk ke Indonesia,

\footnotetext{
${ }^{4}$ Imam, Adlin, 'Faktor-Faktor Yang Mempengaruhi Impor Barang Konsumsi Di Indonesia' (2013) vol.1 Jurnal Kajian Ekonomi dan Pembangunan.[2].

5 Rachma Fitriati. Menguak Daya Saing UMKM Industri Kreatif: Sebuah Riset Tindakan Berbasis Soft Systems Methodology (Yayasan Pustaka Obor Indonesia 2015).[78].
} 
atau jika tidak dapat menghambat paling tidak barang-barang ini dapat dikenakan bea masuk sehingga berujung terhadap harga jualnya yang akan mengalami kenaikan karena harus terkena tarif bea masuk. Pemerintah selain menurunkan nilai ambang batas bagi barang impor juga melakukan berbagai usaha untuk tetap melindungi pelaku usaha domestik dari banyaknya produk impor murah yang membanjiri pasar. Perlindungan yang diberikan ditujukan untuk memperkuat posisi pelaku usaha domestik didalam negeri agar dapat bersaing dengan produk impor, upaya yang dilakukan adalah dengan memberikan bantuan kepada pelaku usaha mikro. Bantuan ini diharap dapat dimanfaatkan untuk meningkatkan produksi dan kualitas dari produk tersebu, dengan meningkatnya jumlah produksi dan kualitas akan mempengaruhi minat beli masyarakat terhadap produk domestik hasil pelaku usaha dalam negeri.

Pemerintah berupaya sebisa mungkin untuk selalu melindungi pelaku usaha utamanya dalam menghadapi pasar bebas yang penuh dengan serbuan produk impor. Sebisa mungkin pemerintah mengantisipasi lonjakan produk impor dengan memperketat peraturan mengenai perlindungan bagi pelaku usaha. Keberadaan Undang-Undang nomor 5 tahun 1999 dan Peraturan Menteri Nomor 119/PMK.010/ 2019 diharap dapat melindungi pelaku usaha dari adanya pasar yang berpotensi mengandung persaingan tidak sehat didalamnya, sehingga dengan minimnya persaingan tidak sehat yang terjadi akan mewujudkan terciptanya kesejahteraan bagi seluruh masyarakat khususnya pelaku usaha.

\section{Dampak De Minimis Bagi Pelaku Usaha}

Perlindungan yang diberikan pemerintah bagi pelaku usaha domestik berupa penurunan nilai de minimis bea masuk impor barang yang semula sebesar USD 75 menjadi USD 3 membawa angin baik bagi pelaku usaha. Sebelumnya produk yang memiliki harga diatas USD 75 akan dikenakan bea masuk impor barang, namun dengan adanya pengaturan ini mulai pada awal tahun 2020 ini barang yang memiliki harga lebih dari USD 3 akan dikenakan bea masuk. Munculnya kebijakan baru ini diharap dapat menekan banyaknya produk impor yang masuk ke Indonesia dengan 
harga yang relatif murah. Pelaku usaha tentu saja merasakan dampak dari adanya penurunan nilai de minimis ini. Dampak yang dirasakan oleh pelaku usaha tidak hanya berimbas terhadap pemasukan saja tetapi kepada sektor lapangan pekerjaan yang tersedia.

Penurunan nilai de minimis ini berdampak terhadap harga barang impor yang memasuki indonesia, karena barang dengan harga lebih dari USD 3 dikenakan bea masuk maka produk dengan harga tersebut mengalami kenaikan harga bila memasuki indonesia, dengan begitu konsumen akan memilih membeli produk buatan lokal yang harganya lebih murah karena diproduksi langsung didalam negeri. Dampak tidak langsung yang juga dirasakan adalah penyerapan tenaga kerja, apabila nantinya pelaku usaha domestik menerima permintaan yang banyak karena konsumen beralih kepada produk lokal maka pelaku usaha akan berusaha untuk meningkatkan pelayanan dengan menambah pekerja agar produksi barang semakin efisien. Penurunan de minimis ini harus diimbangi dengan perilaku pelaku usaha yang kooperatif. Harga barang yang dijual oleh pelaku usaha domestik sebisa mungkin tidak mudah naik agar konsumen tidak mencari barang pengganti dari produk impor dengan harga yang lebih murah. Harga merupakan salah satu aspek yang dipertimbangkan oleh konsumen dalam melakukan pembelian. ${ }^{6}$ Pelaku usaha domestik dengan adanya kemudahan dalam memasarkan produknya didalam negeri diharap dapat lebih memaksimalkan berbagai platform belanja yang ada di Indonesia. Platform e-commerce yang saat ini banyak digunakan oleh masyarakat untuk membeli barang akan sangat membantu pemasaran suatu produk milik pelaku usaha domestik. Pelaku usaha harus turut serta mengikuti perkembangan jaman dengan cara memasarkan produknya melalui platform digital. Presiden Joko Widodo sendiri memberikan pernyataan dalam acara Anugerah Bangga Buatan Indonesia tahun 2020 bahwa dengan adanya kemudahan melalui kebijakan ini harus dimaksimalkan juga oleh pelaku usaha domestik untuk memaksimalkan penggunaan

\footnotetext{
${ }^{6}$ Agnes Ligia Pratisitia Walukow, dan Lisbeth Mananeke, 'Pengaruh kualitas produk, harga, promosi dan lokasi terhadap keputusan Pembelian konsumen Di Bentenan Center Sonder Minahasa' (2014) 2 Jurnal EMBA: Jurnal Riset Ekonomi, Manajemen, Bisnis dan Akuntansi.[1748].
} 
platform digital agar semakin berkembangnya e-commerce ini tidak dikuasai oleh produk impor. Pada intinya dampak yang didapatkan oleh pelaku usaha domestik dengan adanya penurunan nilai bea masuk barang ini adalah semakin mudahnya memasarkan produk didalam negeri karena hambatan dari banyaknya produk impor yang beredar sudah berkurang. Semakin banyaknya jumlah produk dalam negeri yang digunakan oleh konsumen akan meningkatkan permintaan akan suatu barang sehingga pelaku usaha akan semakin gencar melakukan proses produksi, dimana proses produksi akan membutuhkan lebih banyak tenaga kerja yang mana akan meningkatkan jumlah pekerja dalam suatu usaha produksi. Semakin berkurangnya jumlah pengangguran akan berdampak kepada tingkat kesejahteraan masyarakat Indonesia yang semakin meningkat.

\section{Konsep Persaingan Usaha Yang Sehat}

1. Terdapat banyak penjual dan pembeli

Penjual merupakan pihak yang menawarkan dan menyediakan suatu produk yang nantinya akan dijual kepada konsumen. Penjual dalam melakukan penawaran akan melihat pangsa pasar yang akan dituju agar nantinya produk yang dijual memiliki target konsumen yang tepat dan sesuai dengan permintaan dari pasar. Persaingan yang sehat didalamnya terdapat banyak penjual yang ada di dalam sebuah pasar. Jumlah penjual yang banyak ini akan menciptakan persaingan yang sehat karena konsumen dapat membandingkan dengan produk serupa yang terdapat di pasar tersebut, yang dilakukan konsumen sebelum membeli suatu produk diantaranya seperti membandingkan kualitas dan harga produk tersebut. Jumlah penjual yang banyak akan membuat konsumen dapat dengan leluasa untuk memilih mana diantara banyaknya produk yang sesuai dengan keinginan dari segi kualitas maupun harga yang sesuai dengan kemampuan, dengan banyaknya penjual yang ada di dalam suatu pasar bila di imbangi dengan banyaknya konsumen maka harga produk yang dijual dipasar akan relatif stabil dan tidak mudah mengalami perubahan baik itu kenaikan harga maupun penurunan harga, karena banyaknya penjual di dalam pasar menyebabkan 
konsumen memiliki banyak pilihan dengan leluasa, sehingga pedagang tidak dapat memonopoli suatu produk untuk dimainkan harganya. Banyaknya pembeli dapat menjadi indikasi suatu persaingan yang sehat, karena dengan banyaknya pembeli dan penjual yang ada dalam suatu pasar akan membuat keadaan pasar tidak dikendalikan oleh satu atau sebagian pelaku usaha saja. Seimbangnya penawaran dan permintaan yang ada di pasaran akan membuat harga produk yang ada di pasar menjadi stabil dan terkendali. Dalam hukum persaingan usaha, pembeli dilindungi dari beberapa tindakan yang nantinya akan merugikan pembeli, seperti adanya kegiatan monopoli, penguasaan pasar, dan monopsoni. Kegiatan-kegiatan yang dilarang dalam undang-undang nomor 5 tahun 1999 ini nantinya akan merugikan pembeli contohnya seperti tidak stabilnya pasokan barang yang nantinya akan mempengaruhi harga barang di pasaran. Pembeli dalam melakukan kegiatan jual beli harus mendapat informasi yang sebenar-benarnya terkait produk yang akan dibeli, bila pelaku usaha tidak memberikan informasi dengan benar kepada pembeli, selain akan merugikan pembeli juga akan mempengaruhi tingkat kepercayaan pembeli terhadap pelaku usaha tersebut, karena dalam jual beli juga harus dilandasi dengan kepercayaan. Bila dalam ruang lingkup perdagangan melalui sistem elektronik yang lebih banyak menggunakan e-commerce, pembeli sangat dimudahkan dalam melakukan pembelanjaan online. Kemudahan dan efisiensi yang ditawarkan oleh e-commerce membuat pembeli nyaman untuk melakukan pembelian produk disini dari pada harus pergi ke pasar maupun toko yang berbasis offline. Mulai dari kemudahan dalam pencarian produk yang dicari, pembeli hanya harus memasukkan nama produk ke pencarian di dalam aplikasi e-commerce, lalu banyaknya produk yang dapat dipilih dari berbagai penjual karena dalam suatu e-commerce penjual datang dari seluruh daerah Indonesia bahkan dari luar negeri. Hal selanjutnya yang juga menjadi daya tarik bagi pembeli untuk melakukan pembelanjaan online adalah seringnya penyedia layanan $e$-commerce memberikan penawaran berupa promosi yang selalu dilakukan setiap bulan. Penawaran ini sangat menarik minat pembeli. Contohnya: promo gratis biaya 
kirim ke rumah pembeli, karena proses jual beli dilakukan secara online maka pelaku usaha perlu mengirimkan barang yang dibeli oleh konsumen ke rumah yang bersangkutan maka dengan adanya promosi ini akan menguntungkan pembeli tersebut karena menghemat biaya pengiriman, lalu terdapat promo cashback yang juga selalu ditawarkan oleh penyedia layanan e-commerce. Pembeli yang ada didalam platform e-commerce juga terdapat banyak, karena sekali lagi transaksi yang dilakukan melalui media internet dimana para pihak tidak harus bertemu langsung, maka dari itu pembeli juga berasal dari seluruh Indonesia sampai ke luar negeri. Banyaknya jumlah pembeli dapat berpengaruh terhadap daya beli masyarakat. Pengaruh ini dapat dilihat melalui dua sisi yaitu dari sisi ekspor dan impor, apabila ekspor barang ke luar negeri mengalami peningkatan maka artinya permintaan akan barang meningkat yang berdampak dengan banyaknya masyarakat yang mendapat pekerjaan karena naiknya permintaan untuk produksi. Banyaknya masyarakat yang bekerja akan meningkatkan pendapatan perkapita di suatu wilayah, karena pendapatan bertambah maka daya beli masyarakat juga naik terhadap barang-barang, lalu bila dilihat dari sisi impor, jika banyak impor yang masuk ke Indonesia maka produksi dalam negeri mengalami penurunan yang mengakibatkan banyak pekerja kehilangan pekerjaan karena menurunnya permintaan. Dengan begitu pendapatan rata-rata masyarakat akan berkurang dan menyebabkan daya beli masyarakat yang menurun karena semakin sedikitnya pemasukan masyarakat. ${ }^{7}$

\section{Homogenous Product}

Homogenous Product berarti produk yang dijual bersifat homogen. Produk homogen memiliki makna dapat memuaskan pembeli yang membelinya tanpa harus menunjukkan bahwa produk tersebut berasal dari suatu brand ataupun pelaku usaha tertentu. Pembeli dalam melakukan pembelian berdasar kepada kegunaan dari produk tersebut, bukan dari siapa pelaku usaha yang

\footnotetext{
7 Sedyaningrum, M., \& Nuzula, N. F., 'Pengaruh Jumlah Nilai Ekspor, Impor Dan Pertumbuhan Ekonomi Terhadap Nilai Tukar Dan Daya Beli Masyarakat Di Indonesia Studi Pada Bank Indonesia Periode Tahun 2006: iv-2015' (2016) 34 Jurnal Administrasi Bisnis.[121].
} 
memproduksinya maupun merek apa yang tercantum di kemasannya, karena pembeli melakukan pembelian barang atas dasar kegunaan suatu produk maka seluruh pelaku usaha di anggap dapat membuat produk maupun jasa sesuai dengan quality dan ciri yang sama. Dengan adanya produk yang serupa maka pelaku usaha tidak memerlukan promosi yang berlebihan mengenai produknya karena pembeli akan menentukan pilihannya berdasarkan dari kegunaan produk tersebut. Pembeli tidak memiliki acuan tertentu terhadap suatu pelaku usaha yang menjual barang, semua penjual sama tingkatannya karena produk yang mereka hasilkan memiliki kegunaan yang serupa. Model produk yang homogen ini tidak dapat mempengaruhi harga barang yang beredar di dalam sebuah pasar, tetapi barang tersebut hanya mengikuti harga yang sudah ada di pasaran. ${ }^{8}$ Berbeda dalam online markets, suatu produk yang sedang trending dan memiliki ulasan yang baik dalam review pembeli dapat mempengaruhi harga dari homogeneous products. ${ }^{9}$ Produsen memiliki pola pikir bahwa produk mereka sedang mengalami peningkatan permintaan dikarenakan efek dari adanya tren dan ulasan yang baik maka mereka akan sedikit menurunkan harga dari produk mereka dengan tujuan dapat lebih menarik minat pelanggan karena harga yang lebih rendah. ${ }^{10}$ Pelaku usaha ini berani mengambil resiko dengan menurunkan harga dengan pemikiran bahwa pelanggan yang membeli produk mereka akan lebih banyak, maka dengan banyaknya pelanggan tersebut, akan menutup kerugian akibat dari rendahnya harga barang.

3. Adanya efisiensi

Menurut Sutan Remy Sjahdeini efisiensi yang ingin di wujudkan dalam Undang-Undang Nomor 5 tahun 1999 dapat dibedakan menjadi 2 yaitu efisiensi bagi pelaku usaha dan efisiensi bagi konsumen. Bagi pelaku usaha dapat di katakan efisiensi jika dapat menghasilkan produk dengan biaya yang paling

\footnotetext{
${ }^{8}$ Paul A. Samsuelson dan William D. Nordhaus, Ilmu Mikro Ekonomi (Media Global Edukasi 2003).[169].

${ }^{9}$ Kocas, Cenk, and Can Akkan, 'How trending status and online ratings affect prices of homogeneous products' (2016) International Journal of Electronic Commerce.[389].

${ }^{10}$ ibid.
} 
rendah karena menggunakan sumber daya yang sesedikit mungkin, sementara efisiensi bagi konsumen dapat dilihat bila konsumen telah membeli barang dari pelaku usaha dengan harga yang sudah disepakati. Terdapat pemikiran ahli yang sejalan dengan adanya Undang - Undang nomor 5 tahun 1999, yaitu Richard Postner, Postner mengemukakan bahwa efisiensi mengutamakan dari adanya kemanfaatan dan kegunaan. Efisiensi adalah penggunaan sumber daya sebanyak mungkin sehingga nilai dari suatu produk dapat dihasilkan secara maksimal. ${ }^{11}$ Efisiensi berkaitan dengan keuntungan yang meningkat tanpa harus merugikan pihak manapun. Efisiensi juga bisa dibedakan menjadi efisiensi produktif dan efisiensi alokatif. Efisiensi produktif didalamnya terdapat dua hal yang harus terpenuhi, yang pertama dalam setiap tingkat produksi biaya yang dikeluarkan harus seminimal mungkin lalu yang kedua adalah semua industri dalam memproduksi barang harus dalam biaya rata-rata yang terendah, dengan dua hal ini maka efisiensi telah dianggap optimal dengan biaya dalam pengeluaran produksi paling minimal. Mengenai efisiensi alokatif berarti dalam memproduksi barang, pelaku usaha harus mencapai keadaan dimana harga barang setara dengan biaya marjinal. ${ }^{12}$

4. Tidak ada deadweight loss

Deadweight Loss merupakan akibat dari adanya pelaku usaha yang melakukan monopoli di dalam pasar. Jumlah surplus konsumen dan surplus pelaku usaha dalam pasar monopoli ini menyebabkan perekonomian mengalami kerugian karena jumlahnya lebih sedikit dari pasar persaingan sempurna. Pembatasan output dalam pasar membuat harga menjadi tinggi sehingga menyebabkan deadweight loss yang harus ditanggung akibatnya oleh konsumen. Pelaku usaha yang memonopoli pasar melakukan pengurangan pasokan barang yang di produksi sehingga menimbulkan kelangkaan di masyarakat. Permintaan masyarakat masih tinggi sementara barang yang diproduksi berkurang

${ }^{11}$ Handayani Otih, et al. 'Analisis Pasar Bersangkutan Dalam Hukum Persaingan Usaha Pada Era Disrupsi 4.0 (Bisnis Online Versus Bisnis Konvensional)’ (2020) 3 Soumatera Law Review.[57].

12 ibid. 
maka menyebabkan harga barang menjadi naik dan memberikat profit yang berlebihan hingga tidak normal kepada pelaku usaha tersebut. ${ }^{13}$ Pelaku usaha yang melakukan praktek ini merupakan perusahaan yang memiliki market power besar sehingga dapat mempengaruhi harga di pasaran. Munculnya kondisi deadweight loss ini membuat keadaan di dalam pasar menjadi tidak efisien. Kondisi yang tidak efisien ini dianggap sebagai kegagalan pasar dalam menciptakan iklim persaingan usaha yang sehat. Peran pemerintah disini bisa mengambil sebuah langkah untuk menormalkan kembali keadaan pasar yang mengalami deadweight loss.

5. Tidak adanya persaingan usaha yang dilarang

Pelaku usaha untuk menciptakan persaingan usaha yang sehat tentu saja harus menghindari adanya tindakan yang dapat menyebabkan persaingan yang dilarang. Undang - Undang Nomor 5 tahun 1999 didalamnya memuat perjanjian yang dilarang dan kegiatan yang dilarang. Pernjanjian yang dilarang antara lain terdapat : oligopoli, penetapan harga, pembagian wilayah, pemboikotan, kartel, trust, oligopsoni, integrasi vertikal, perjanjian tertutup, dan yang terakhir perjanjian dengan pihak luar negeri, sementara kegiatan yang dilarang antara lain: monopoli, monopsoni, penguasaan pasar, dan persekongkolan. Pasal mengenai perjanjian yang dilarang terdapat dalam pasal 4 sampai pasal 16 , sementara pasal tentang kegiatan yang dilarang diatur dalam pasal 17 sampai dengan 24. Dalam pembuktiannya Undang-Undang Nomor 5 tahun 1999 menggunakan pendekatan per se illegal dan pendekatan rule of reason. Rule of reason berpusat terhadap akibat yang timbul dari adanya kegiatan atau perjanjian, apakah hal tersebut menimbulkan pelanggaran dalam persaingan usaha. Penegak hukum harus bisa menjabarkan bukti-bukti yang ada bahwa suatu pelaku usaha telah melanggar batas sesuai aturan yang ada di suatu pasal

${ }^{13}$ Pratomo Gigih, 'Analisis Welfare Loss Konsumen Sambungan Langsung Jarak Jauh Telepon Tetap Di Indonesia’ (2010) 8 Equilibrium: Jurnal Ekonomi-Manajemen-Akuntansi.[190]. 
dalam undang-undang tersebut. ${ }^{14} \mathrm{Per}$ Se illegal tidak memerlukan pembuktian terlebih dahulu karena perjanjian atau kegiatan yang dilakukan sudah dengan jelas tertulis bahwa itu merupakan hal yang dilarang untuk dilakukan. Perjanjian maupun kegiatan yang tergolong dalam hal ini pastinya tidak memiliki manfaat sosial dan bersifat anti persaingan. Melihat dari kompenen persaingan usaha sehat yang sudah dijelaskan diatas, dapat ditarik kesimpulan bahwa adanya penurunan nilai de minimis di dalam Peraturan Menteri Keuangan Nomor 199/ PMK.010 /2019 tidak melanggar konsep persaingan usaha yang sehat.

\section{Kebijakan Bea Masuk Impor}

Barang-barang yang datang dari luar negeri akan di kirim menggunakan sarana pengangkutan yang berasal dari dalam atau luar daerah pabean menuju ke daerah pabean. Daerah pabean merupakan daerah di Republik Indonesia yang meliputi area darat, perairan, serta ruang udara di atasnya serta daerah zona ekonomi eksklusif dan landas kontinen yang juga berlaku undang-undang kepabeanan di dalamnya. Pengangkut yang jasa angkutannya akan tiba wajib melaporkan ke kantor pabean tujuan mengenai rencana kedatangannya. Jasa pengangkut ini harus melengkapi data surat muatan, airway bill bagi angkutan udara, dan bill of lading untuk angkutan laut. Semua urusan pemberitahuan mengenai pabean bagi barang kiriman dari luar negeri dilakukan oleh importir. Namun bila importir berhalangan untuk mengurus urusan kepabeanan maka bisa diberikan kuasa kepada badan usaha yang disebut Pengusaha Pengurusan Jasa Kepabeanan (PPJK).

Pemeriksaan guna memeriksa barang kiriman dari luar negeri ini di lakukan di dalam daerah pabean, namun karena keterbatasan waktu dan tempat serta guna lebih menekankan efisiensi maka Menteri Keuangan memutuskan untuk dapat dilakukan pemeriksaan kepabeanan di luar daerah pabean oleh Direktorat Jenderal Bea dan Cukai, mengenai pengaturan mengenai pemeriksaan pabean terdapat dalam pasal 3 Undang-Undang Nomor 10 Tahun 1995 tentang Kepabeanan sebagaimana

\footnotetext{
${ }^{14}$ Daniel V., et.all., comprehensive business law: principles and cases (Kent publishing Company 1987).[1042].
} 
telah diubah dengan Undang-Undang Nomor 17 Tahun 2006.

Dalam proses pemeriksaan kepabeanan tidak hanya dilakukan dengan pemeriksaan fisik saja namun juga pemeriksaan kelengkapan dokumen terkait. Pembayaran terkait bea masuk ini dilakukan sendiri oleh pihak yang bersangkutan atau di sebut self assasment. Berhasil atau tidaknya sistem pemungutan pajak self assessment ini tentunya sangat bergantung pada pengetahuan dan pemahaman masyarakat, khususnya wajib pajak, akan substansi peraturan perundang-undangan pajak yang terkait dengan sistem self assessment ini. ${ }^{15}$ Penetapan tarif dan nilai pabean guna perhitungan bea masuk tetap menjadi kewenangan pejabat bea dan cukai yang disampaikan melalui pemberitahuan pabean yang berasal dari importir. Bagi importir yang salah melakukan perhitungan untuk bea masuk sehingga membuat pembayaran bea masuk tidak sesuai dengan aturan yang seharusnya maka dapat dikenai sanksi administrasi sebesar minimal 50\% (lima puluh persen) atau maksimal 1000\% (seribu persen) dari bea masuk yang kurang di bayarkan, besarnya denda yang harus dibayarkan tergantung dengan besarnya total kekurangan dalam pembayaran bea masuk. Semakin besar jumlah yang kurang dibayar akan semakin besar pula denda yang akan didapatkan. Pengaturan mengenai sanksi denda ini terdapat dalam pasal 6 Peraturan Menteri Keuangan Republik Indonesia Nomor 99/ PMK.04/2019 tentang Tata Cara Penghitungan Sanksi Administrasi Berupa Denda di Bidang Kepabeanan. Dengan adanya pembebasan bea masuk ini diharapkan dapat menciptakan kondisi dimana arus beredarnya barang dapat tertata dan memperlancar kepabeanan di bidang impor. Sebelum adanya Peraturan Menteri Keuangan Nomor 119/PMK.010/2019, besaran bea masuk yang ditetapkan di indonesia adalah sebesar maksimal USD 75.00, hal ini tertuang dalam Peraturan Menteri Keuangan Nomor 112/PMK.04/2018 pada pasal 13 ayat (1). Saat ambang nilai bea masuk masih sebesar USD 75.00, besaran tersebut terbilang masih tinggi. Tujuan di adakannya pembebasan bea masuk adalah untuk membuat lancar kegiatan impor, yang mana sebagai pelaksaan dari perdagangan internasional

\footnotetext{
${ }^{15}$ Sarwirini, 'Implementasi Restorative Justice Dalam Penegakan Hukum Pajak' (2014) 29 Yuridika.[381].
} 
maka hal ini dimaksudkan agar barang yang akan masuk ke Indonesia mendapat kemudahan. Namun dampak yang di timbulkan atas kebijakan ini adalah negara mengeluarkan devisa yang banyak untuk kegiatan impor ini. Lalu kebijakan ini juga berdampak kepada masyarakat dimana semakin banyaknya produk dari luar negeri yang masuk ke Indonesia menyebabkan kegiatan produksi di dalam negeri melemah karena keadaan di dalam pasar yang lebih di penuhi oleh barang dari luar negeri, sama halnya dengan di dalam e-commerce juga banyak bertebaran produk yang dikirim dari luar negeri. Dengan melemahnya produksi dapat berpengaruh kepada banyaknya lapangan pekerjaan. Bila produksi melemah maka pelaku usaha pasti akan mengurangi jumlah produksi dan jumlah pekerja karena sedikitnya pemasukan akan berakibat pada keuangan pelaku usaha. Namun setelah adanya pengaturan terbaru dalam Peraturan Menteri Keuangan Nomor 119/PMK.010/2019 nilai ambang batas untuk barang kiriman turun, dari yang mulanya USD 75 menjadi USD 3 hal ini tertuang dalam pasal 13 ayat (1) itu berarti barang kiriman yang harganya dibawah USD 3, tidak perlu membayar bea masuk. Terhadap barang dengan harga diatas USD 3 dipungut bea masuk dengan tarif pembebanan sebesar 7,5\%. Perubahan ambang batas ini sangat berpengaruh terhadap kegiatan impor di Indonesia karena perubahannya yang sangat signifikan dibandingkan dengan sebelumnya. Dengan begitu kebijakan terbaru ini akan dapat melindungi pelaku usaha yang berskala kecil dari serbuan barang kiriman dari luar negeri. Dengan begitu produk lokal dan produk dari luar negeri akan bisa setara dan seimbang.

Pengurangan nilai ambang batas ini juga berpengaruh terhadap defisit neraca perdagangan dan membuat stabil nilai tukar Rupiah terhadap Unites States Dollar (USD). Namun pelaku usaha dari luar negeri yang terdampak akan adanya kebijakan penurunan de minimis ini selalu mencari celah untuk dapat memasukkan barang kiriman ke Indonesia tanpa harus membayar bea masuk. Salah satu modus yang dilakukan adalah dengan melakukan splitting. Splitting merupakan kegiatan yang bertujuan untuk memecah barang dengan harga yang tinggi menjadi beberapa bagian guna mendapatkan pembebasan bea masuk. Tetapi modus ini hanya bisa dilakukan untuk barang-barang tertentu saja. Menanggapi hal ini Direktorat 
Jenderal Bea dan Cukai menegaskan bahwa mereka akan memperketat pemeriksaan di setiap pintu tempat kedatangan barang kiriman dari luar negeri. Data yang masuk akan di cocokkan dengan consignment note yang dilampirkan oleh pengirim. Bila hal tersebut tidak sesuai dengan dengan yang dilampirkan maka petugas akan menetapkan biaya bayar tambahan kepada pemilik barang. Dalam tiga tahun terakhir ini dimulai pada tahun 2017, angka impor menurut catatan dokumen impor kegiatan e-commerce melalui barang kiriman yang ada di Indonesia sebesar 6,1 juta paket lalu meningkat pada tahun 2018 sebanyak 19,57 juta paket dan semakin melonjak pada 2019 sebesar 57,92 juta paket. Dengan adanya kebijakan mengenai penurunan bea masuk impor bagi barang kiriman ini merupakan upaya pemerintah untuk melindungi industri dan pelaku usaha di dalam negeri, karena banyaknya barang kiriman dari luar negeri yang masuk ke Indonesia memiliki harga dibawah USD 75,00. Yang menyebabkan barang-barang ini tidak dikenai pajak saat masuk ke Indonesia. Dengan kebijakan baru mengenai bea masuk impor barang kiriman yang berubah menjadi USD 3,00. Diharap dapat melindungi industri yang ada didalam negeri dan memacu produsen lokal untuk semakin mengembangkan usahanya di negeri sendiri. Karena sudah adanya kebijakan yang secara tidak langsung melindungi produksi lokal dari banyaknya produk impor yang masuk ke Indonesia.

\section{Kesimpulan}

Lahirnya pengaturan yang ada di dalam Peraturan Menteri Keuangan Nomor 119/PMK.010/2019 diharapkan dapat melindungi kepentingan nasional dengan meningkatkan kesejahteraan masyarakat khususnya pelaku usaha, sejalan dengan tujuan pembuatan Undang-Undang Nomor 5 Tahun 1999 yaitu untuk meningkatkan kesejahteraan masyarakat. Penurunan nilai de minimis merupakan langkah pemerintah untuk melindungi pelaku usaha domestik dengan harapan dapat membatasi banyaknya produk impor yang masuk ke Indonesia, khusunya barang yang berasal dari platform e-commerce. Adanya pengaturan ini diharap dapat mendatangkan keuntungan bagi pelaku usaha berupa peningkatan permintaan akan barang karena seiring dengan meningkatnya harga pada produk impor. Adanya 
penurunan nilai de minimis ini telah memenuhi unsur persaingan usaha yang sehat karena didalamnya sudah sejalan dengan komponen persaingan usaha yang sehat. Kegiatan membeli merupakan hak konsumen untuk menentukan produk apa yang akan dibelinya. Adanya kenaikan harga akibat diadakannya bea masuk pada produk impor adalah resiko yang harus ditanggung oleh pelaku usaha pengirim barang dari luar negeri tersebut karena telah memasuki pasar domestik.

\section{DaftarBacaan}

\section{Buku}

Candra Ahmadi dan Dadang Hermawan, E-Business \& E-Commerce (Andi Offset 2013).

Daniel V., et.all., comprehensive business law: principles and cases (Kent publishing Company 1987).

Paul A. Samsuelson dan William D. Nordhaus, Ilmu Mikro Ekonomi (Media Global Edukasi 2003).

Rachma Fitriati. Menguak Daya Saing UMKM Industri Kreatif: Sebuah Riset Tindakan Berbasis Soft Systems Methodology (Yayasan Pustaka Obor Indonesia 2015).

\section{Jurnal}

Ferdiansyah, 'Globalisasi Ekonomi, Integrasi Ekonomi Global, Dinamika Pasar modal \& Kebutuhan Standar Akuntasi Internasional' (2016) Jurnal Akuntasi STIE STAN.

Imam, Adlin 'Faktor-Faktor Yang Mempengaruhi Impor Barang Konsumsi di Indonesia' (2013) Jurnal Kajian Ekonomi dan Pembangunan.

Sedyaningrum, M., \& Nuzula, N. F. 'Pengaruh Jumlah Nilai Ekspor, Impor Dan Pertumbuhan Ekonomi Terhadap Nilai Tukar Dan Daya Beli Masyarakat Di Indonesia Studi Pada Bank Indonesia Periode Tahun 2006' (2015) Jurnal Administrasi Bisnis.

Kocas, Cenk, and Can Akkan. 'How trending status and online ratings affect prices of homogeneous products' (2016) International Journal of Electronic Commerce. 
Handayani Otih, et al. 'Analisis Pasar Bersangkutan Dalam Hukum Persaingan Usaha Pada Era Disrupsi 4.0 (Bisnis Online Versus Bisnis Konvensional)' (2020) Soumatera Law Review.

Pratomo Gigih, 'Analisis Welfare Loss Konsumen Sambungan Langsung Jarak Jauh Telepon Tetap Di Indonesia' (2010) Equilibrium: Jurnal EkonomiManajemen-Akuntansi.

Sarwirini, 'Implementasi Restorative Justice Dalam Penegakan Hukum Pajak' (2014) Yuridika.

\section{Peraturan Perundang-undangan}

Undang-Undang Dasar Negara Republik Indonesia Tahun 1945.

Undang-Undang Nomor 5 Tahun 1999 tentang Larangan Praktek Monopoli dan Persaingan Usaha Tidak Sehat.

Peraturan Menteri Keuangan Nomor 199/ PMK.010 / 2019 tentang Kepabeanan, Cukai, dan Pajak atas Impor Barang Kiriman.

Peraturan Pemerintah Republik Indonesia Nomor 80 tahun 2019 tentang Perdagangan Melalui Sistem Elektronik. 